Л. А. Білоконенко

канд. філол. наук, доцент

\title{
МОЖЛИВОСТІ КОНТЕНТ-АНАЛІЗУ ПРИ ВИЗНАЧЕННІ ОЗНАК ЧОЛОВІЧОГО ТА ЖІНОЧОГО СПІЛКУВАННЯ
}

У статті схарактеризовано можливості контент-аналізу художнього твору з точки зору гендерної проблематики; визначено аспекти досліджень, тип вибірки, особливості кодування вибірки, яка може бути застосована за цим методом; пояснено особливості використання методу при описі ознак чоловічого та жіночого спілкування.

Сучасне суспільство все частіше вимагає вивчення особливостей статі людини у психологічному плані, адже роль чоловіка та жінки значно змінилися. Це питання порушується в соціальній психології, що визнає гендер біологічною характеристикою, яка лежить в основі визначення чоловіка чи жінки. Психологи $[1 ; 3 ; 6 ; 12 ; 13]$ вважають, що існує лише дві причини, через які люди хочуть відповідати гендерним очікуванням - суспільна норма та суспільний тиск. Норма вимагає підлаштування під суспільне очікування, а тиск виникає, коли особа спирається в соціальних питаннях не на власне світосприйняття, а на інформаційний тиск суспільства. Обов'язковість традиційно жіночої чи чоловічої ролі перш за все базується на емоціональності. Емоції та почуття в осіб обох статей однакові, різними $є$ лише їх вираження. Саме мова дає можливість відобразити і закріпити «норму», яка репрезентує міру емоційності жінки / чоловіка.

Одним із методів визначення та оцінки специфічних характеристик текстів є контент-аналіз. Уважаємо за можливе використання контентаналізу при виявленні змістових одиниць інформації в художньому тексті, зокрема і з позиції гендеру. Отже, мета нашого дослідження - довести, що контент-аналіз підвищує об'єктивність характеристики диференційних ознак чоловічого / жіночого мовлення.

Зміщення акцентів у бік інтегрального вивчення проявів «фемінінності» та «маскулінності» в мові відбувається з кінця 80 -х років, що пов’язано 3 виникненням гендерного мовознавства. 3 II пол. 80 -х років виникають активні дискусії з приводу впливу факторів статевої приналежності на мову. Розуміння того, що фактор статі необхідно розглядати не лише з біологічної, а й, насамперед, із соціальної точки зору, спричинило появу досліджень, результати яких відіграють помітну роль у громадській дискусії стосовно проблем рівноправності чоловіків і жінок [7; 13]. У ході цієї дискусії з'ясовуються диференційні ознаки чоловічого та жіночого сексолекту на різних рівнях мовної системи; походження цих особливостей, умови вияву їх параметрів.

У вивченні жіночої і чоловічої вербальної поведінки можна виокремити ряд напрямів, які виявляють розбіжності на різних мовних рівнях, ди- 
ференціацію вербальних стереотипів у сприйнятті жінок / чоловіків; визначають семантичні розбіжності, які спричиняють розподіл соціальних функцій у суспільстві (соціальна природа мови жінок і чоловіків); будують психолінгвістичні теорії, які характеризують «жіночу» і «чоловічу» мови; пояснюють виявлені фактори (установлення зв'язку з різними аспектами картини світу) $[5,70]$.

Гендерні дослідження останніх років все більше привертають увагу спеціалістів, чиї наукові інтереси знаходяться в царині вивчення художніх текстів. Аналіз мови художніх творів дозволяє встановлювати особливості функціонування лексичних одиниць у тексті, спостерігати інновації семантико-синтаксичних відношень між структурними компонентами контексту, фіксувати направлення естетичної і філософської думки письменника [9, 24-25]. Гендерний аспект дозволяє зрозуміти природу особистості, унікальність і складність існування людини в реальному світі. Гендерні дослідження дозволяють більш глибоко аналізувати характер діючого персонажа твору чи автора тексту. Аналіз художнього тексту переважно зупиняється на констатації існуючої в літературному творі опозиції «чоловік / жінка». У центрі уваги дослідників при цьому виявляються або особисті пристрасті автора (його моральний, естетичний, етичний та ін. ідеали), або ж обставини його (автора) життя. Значна частина світогляду автора це прояв культурного світосприйняття відповідної епохи $[4 ; 5 ; 6]$. Представлений у художньому тексті реальний світ переплітається із світом інформаційним і світом символічним. Перетин цих світів визначає гендерні особливості мови персонажів твору.

Характер мовленнєвого спілкування, його стратегія, стиль, тональність залежать від статусу учасників спілкування. На поведінку й спілкування жінок і чоловіків істотно впливають два чинники: психофізіологічні особливості та гендерні стереотипи: жінки більшою мірою екстравертні, товариські, активні, емфатичні, дбайливі, а чоловіки автономні, настійливі, авторитарні й інтелектуальні. Чоловічий стиль спілкування - активний $\mathrm{i}$ предметний, але змагальний і конфліктний. Для чоловіка зміст спільної діяльності важливіший, ніж індивідуальна симпатія до партнера. Чоловіче спілкування відрізняється емоційною стриманістю. Жінки вільніше і повніше (зокрема, вербально) висловлюють свої емоції, вони здатні до співпереживання. Жіночий вокабуляр характеризується більшою рафінованістю. Жінки уникають «крутих» висловлювань, використовують м'якші форми, віддають перевагу вербальній побудові речення, роблячи акцент на коротші висловлювання, у діалогах рідко формулюють спочатку тему розмови, віддаючи перевагу формам від першої особи. Чоловіки прагнуть до узагальнюючих висловлювань $[10,66]$.

Ознаками стилів чоловічого та жіночого спілкування є:

- для чоловіків найважливішою $є$ інформація: факти, цифри, результати; жінки зорієнтовані на атмосферу спілкування, на інтерактивні, міжособистісні аспекти; 
- чоловіки зорієнтовані на соціальні статуси і владу, пристосовуються до ієрархічних соціальних ролей у комунікації; жінки віддають перевагу партнерській, рівноправній комунікації; прагнуть до знищення соціальних та інших ієрархічних бар'єрів, скорочують дистанцію між собою і партнером у комунікації (чоловіки дистанцію підтримують);

- чоловіки віддають перевагу комунікації асиметричній, а жінки - симетричній;

- мовлення жінок насичене засобами опису почуттів, настроїв, емоцій; вони формулюють свої бажання непрямо, легше за чоловіків «вичитують» імплікатури (що часто стає причиною конфліктів), очікують від чоловіків «відгадування» їхніх бажань; чоловіки зорієнтовані на прямі прохання, вимоги;

- чоловіки формулюють пропозиції прямо; жінки - у вигляді запитань;

- чоловіки частіше, ніж жінки, акцентують увагу на власній позиції, жінки зорієнтовані на загальну атмосферу спілкування;

- у конфлікті жінки частіше відмовляються від своїх поглядів, позицій;

- чоловіки розв'язують конфлікти раціональним способом, за допомогою аргументів і переконань; жінки схильні до емоційного їх вирішення $[2,114]$.

Що стосується аспектів спілкування, пов'язаних із мовним кодом, то дослідники лінгвогендерологічних проблем зазначають, що в мовленні чоловіків простежується більша кількість іменників і дієслів; жінки віддають перевагу прикметникам і прислівникам. У мовленні жінок частіше трапляються актуалізатори, сигнали наявності зворотного зв'язку і уваги до слів співбесідника. Мовний код жінок містить більшу кількість засобів ввічливості. У мовленні жінок частіше спостерігається явище неточного називання предметів; чоловіки ж намагаються називати все точно.

Отже, зовнішні (ситуація, контекст) і внутрішні (соціальні та психологічні) складові спілкування виступають у тісному зв'язку, впливаючи на перебіг комунікації загалом. Таким чином, важко заперечувати, що і в літературних персонажів ми можемо простежити взаємозв'язок між мовною практикою та гендерною ідентифікацією, яка визначає їхню комунікативну поведінку.

Контент-аналіз дозволяє отримати інформацію, яка може вважатися об'єктивною, надійною та вірогідною. Його якість підвищується завдяки застосуванню статистичних підрахунків. Особливо широко метод використовується для вияву прихованих факторів, які характеризують текст. У методичному плані контент-аналіз може бути використаний у трьох аспектах: як основний, як паралельний та як додатковий метод. Якщо останній в основному використовується у психології, то перші два можна застосувати для аналізу тексту. «Контент» (зміст) має вияв у словах, поняттях, темах чи інших повідомленнях, які проявляються в комунікації $[11,17]$. Для отримання результату символічний зміст тексту піддається статистичному підрахунку та фіксується. Позитивом є момент відсутності впливу дослідника 
на текст, адже контент-аналіз є неопитуваним методом, який лише фіксує процес розміщення слів, їх вибір тощо. Метод дозволяє виявити об’єктивну приховану тенденцію в інформації, порівняти значну кількість текстів, отримати одночасно повну та часткову вибірку. Дослідники вважають, що контент-аналіз дає одночасно чотири типи характеристик:

1) частота, яка фіксує міру повторюваності явища;

2) направленість, що визначає способи вияву явища (позитивні / негативні);

3) простір, за допомогою якого фіксується обсяг явища, межі його вияву, він визначається при підрахунку кількості слів, речень, абзаців чи місця опису в тексті;

4) інтенсивність - це сила та міць явища, яке можливо перебільшити чи применшити.

Важливим етапом проведення контент-аналізу є підрахунок виявлених явищ. У тексті можливий підрахунок з маніфестним (відкритим) кодуванням змісту тексту та з латентним (прикритим) кодуванням, яке виявляє імпліцитне значення змісту тексту. Далі створюється кодувальна матриця контент-аналізу.

Отже, контент-аналіз дозволяє або певною мірою відсторонитися від особи автора, його пристрастей, обставин життя - основний аспект або доповнити інший метод аналізу гендерних проблем твору - паралельний аспект.

Якщо в художньому творі на гендерні особливості мови персонажів впливають суспільний тиск і норми, які сформували особистість автора, його інформаційне та символічне світосприйняття, то контент-аналіз, як неопитуваний метод, значно зменшує необхідність урахування всіх цих складових.

Характеризуючи стилі чоловічого та жіночого спілкування, можна використати повну (1) чи часткову (2) вибірку. Перша дає можливість одночасно врахувати чоловічий / жіночий сексолект на різних рівнях мовної системи, особливості, умови їх вияву та параметри оцінки. Друга визначатиме лише необхідне для дослідника явище, наприклад, реєструються саме лінгвістичні одиниці мови жінки, (жінок), жінок певного віку чи соціального стану, жінки в конфлікті з жінкою, у конфлікті з чоловіком. Можлива характеристика стилів чоловічого / жіночого спілкування з позицій: орієнтація на міжособистісне спілкування, наявність рівноправності в комунікації, мовний вияв емоційності, наявність імплікатури, категоричність міркування, використання мовного тиску в конфлікті тощо.

Маніфестне кодування тексту дає можливість для підрахунку використаних чоловіками / жінками слів, фраз, цифр, дій тощо. Ці підрахунки може виконувати комп'ютерна програма, але необхідно враховувати конотацію слів у тексті.

Латентне кодування більше орієнтоване на сприйняття дослідником тексту. Може використовуватися в процесі встановлення чоловічого / жі- 
ночого опису почуттів, емоцій, особливостей синтаксису речень, актуального членування речень, наявності аргументів у спілкуванні, орієнтації на ієрархічні чи соціальні ролі тощо. Можливе поєднання латентного та маніфестного кодування вибірки.

Отже, аналіз тексту художнього твору з точки зору гендерної проблематики може використовувати контент-аналіз, який $є$ методом систематизованої фіксації одиниць змісту. Обрання аспекту аналізу, типу вибірки, типу кодування вибірки залежить від формулювання проблеми. Одиницями аналізу можуть бути різні елементи вибірки. Узагальнення інформації в кодувальній матриці дає можливість для чітких підрахунків. Безперечно, контент-аналіз не може претендувати на вичерпність у дослідженні, адже він обмежений особливостями культурної комунікації. Та різноманітність методів досліджень завжди свідчить про багатогранність інтересів дослідника.

\section{Список використаної літератури}

1. Абубикирова Н. И. Что такое «гендер»? - Гендерные исследования. - 1996. №6. - С. 123-127.

2. Бацевич Ф. С. Основи комунікативної лінгвістики: Підручн. для студентів ВНЗ. - К. Академвидав, 2004.

3. Берн Ш. Гендерная психология. - СПб: Прайм, 2001. - 120 с.

4. Дороніна Т. О. Гендерні дослідження у літературознавстві // Актуальні проблеми філології і методики викладання мов: Зб. наук. праць. - Кривий Ріг, 2003. - C.137 - 143 .

5. Зарецький О. Другий Київський гендерний семінар: [гендерна лінгвістика] // Дивослово. - 2004. - №5 - С. $70-71$.

6. Здравомыслова Е. А., Темкина А. А. Социальное конструирование гендера // Социологический журнал. - 1999. - №3-4. - С. 171-182.

7. Кирилина А. В. Гендер: Лингвистические аспекты. - М.; 1999. - 179 с.

8. Куницына В. Н., Казаринова Н. В., Погольша В. М. Межличностное общение: Уч. для вузов. - СПб: Питер, 2001. - С. 49-53; 233-236.

9. Лисюченко Е. В. Гендерный аспект анализа художественных текстов // Руский язык и литература в учебных заведениях. - 2002. - №3. - С.25 - 27.

10. Петренко О., Ісаєв С., Петренко Д. Мова чоловіків і жінок як одиниця соціолінгвістичного дослідження // Мовознавство. - 1999. - №1. - С.64 - 70.

11. Практикум по общей, экспериментальной и прикладной психологии / Под ред. А. А. Крылова. - СПб: Питер, 2000. - С. 17-19.

12. Пушкарева Л. Н. Гендерный анализ и его применение к изучению культуры // Отечественная история. - 1999. - №1. - С. 19-29.

13. Хрисанова С. Про права людини і гендерну соціологію // Право України. 2001. - №8. - C. 98-101.

\section{Summary}

The article deals with the possibilities of content-analysis of the literary works on the base of the gender problem; the aspects of research, the type of extract which may be used for this type has been defined; we explained the peculiarites of this type usage in the description of the attributes of men's and women's communication process. 